\title{
Web-Based Urban Village Information System Development
}

\author{
Ach Khozaimi, Yudha Dwi Putra Negara*, Ali Syakur \\ Informatic Engineering Departement, University of Trunojoyo Madura, Indonesia
}

\begin{abstract}
The development of increasingly advanced and adequate technology so that information can be accessed quickly, precisely, up-to-date, and accurately has prompted the creation of a system that makes it easier for us to retrieve information anywhere and anytime. One area that is developing is population. So that population data can be recorded properly, it requires good data management or administration. Administrative implementation is still carried out in a traditional manner so that various obstacles arise. Therefore, it is necessary to develop an integrated system for population administration. The stages to develop the Urban Village Data Information System are the data collection stage, the application development stage, and the application testing stage. The design of information systems uses the Waterfall method. The Waterfall method takes a systematic and sequential approach. An Information System has been developed that has been used to assist Urban Village Officers to manage village data. The village information system has the convenience of running it. The Village Information System is easy to use and understand. The Urban Village information system is very helpful for the community, it is also fast and stable.
\end{abstract}

Keywords : Data Information System, Urban Village, Waterfall Method

\section{Introduction}

The development of the world of information from time to time continues to increase and develop [1]-[3]. Along with the rapid progress in the world of science and technology, the need for information is increasing [4], [5]. This is supported by the development of increasingly advanced and adequate technology so that information can be accessed quickly, precisely, up-todate, and accurately [6]. Therefore, we need a system that makes it easier for us to process information anywhere and anytime.

Now, technological developments are also developing in various fields, one of which is the field of population [7], [8]. Activities from the population sector include population census, population relocation, etc., so the importance of population data for administrative needs.

So that population data can be recorded properly, it requires good data management or administration. The thing that is most closely related to population regulation is administration. As we know, administration is still done traditionally, so there are various obstacles. These obstacles include duplication of data, a lot of inaccurate data such as status, increasing family members, etc. In addition, because many processes are done manually, so in the administrative process it can result in the accumulation of files that have the possibility to be lost. And if these files are needed at any time, it will take a long time to find them again.
Therefore, from the constraints that exist in the administration of population data at this time, we are interested in trying to develop an integrated system for population administration. The focus of developing this system is to be able to change population data quickly, briefly and easily through a web application[9], [10]. Data that can be changed include status, education, family members, etc. In this web application, the person who can change the population data in addition to the urban village employees is the Head of the RW. In addition, this system will be equipped with good security in order to maintain data accuracy.

\section{Method}

There are several stages that have been carried out to develop a urban village Data Information System, namely (1) Stages of data collection; (2) stages of application development; (3) Application testing stages [11]-[15]. At the stage of data collection, there are two methods used in data collection, namely interviews and observations. Interview is a dialogue between two or more people in which there are sources to be interviewed and interviewers. The purpose of the interview is to obtain information about the questions asked by the interviewer. In this study, interviews were conducted with one of the representatives of the urban village employees. While observation is a method of collecting data through direct observation in the field. In this case, researchers need information about the workings of the implementation of activities in the village. Therefore, it is necessary to make observations to obtain the 
necessary data. The next stage is the design of Information Systems. Information System Design using the Waterfall method[16]-[20]. In the Waterfall method there are 5 stages, namely the requirements definition stage (needs analysis), system and software design (system design), implementation and unit testing (program code writing), integration and system testing (system testing), operation and maintenance (implementation and maintenance). maintenance). The Waterfall method takes a systematic and sequential approach.

The requirements definition stage or needs analysis is the first stage that forms the basis for the process of making Information Systems. The analysis phase was carried out by means of interviews and observations. After the analysis is carried out, user requirements or user requirements will be formed.

The system and software design stage are the stage for compiling data, the flow of processes that occur in the system, the linkages between processes with one another based on the analysis of the results of user needs. At this stage, two designs will be produced, namely data design and interface design. The data design will produce a Usecase Diagram, while the interface design will produce an interface design that will be applied to the Information System. The implementation and unit testing stage or writing program code is the stage of translating the system design that has been made into commands that are understood by the computer using a particular programming language and database. This stage is the implementation of the system design stage. This Web-Based Urban Village Data Information System application was developed using the PHP language, MySQL database, Java Script programming language, using the SBAdmin 3 Template for a responsive display and using the Codeigniter 3 framework for further optimization in making this website. In its implementation, this application can be run on mobile devices or personal computers that are connected to the internet and have a supported web browser.

The integration and system testing stage are the stage to test the system created to find out the shortcomings of the system before it is used. This test is carried out by system makers and system users. If an error is found during testing, it will be refined again by the developer until the application meets the user's needs. The testing method that will be used is the Blackbox and Mean Opinion Score (MOS) testing.

The operation and maintenance stage are the stage of implementing the system that has been created and tested in the agency environment. Maintenance is carried out so that the use of the system can continue to be optimal and minimize system failures. Maintenance can be carried out periodically on the system, database, and supporting components. Treatment can also be done by making instructions for use.

\section{Result}

At this stage, we will discuss the steps taken to develop a Kelurahan Data Information System based on the stages described in section 2. The requirements definition stage or analysis stage is carried out to explain in detail and describe applications that are built to be effective and meet user needs. In making the Urban Village Data Information System, several methods are used to form user requirements, namely interviews and observations. At the interview and observation stage, the users of the Urban Village Data Information System were obtained, namely the admin. The admin user is a user who fully manages the Urban Village Data Information System. The next stage in system design is to identify the needs of each user. As stated earlier, that in making this system used interview and observation data collection methods to determine the needs of each user that needs to be applied to the application. After knowing the needs of the Village Data Information System users, the Village Data Information System Usecase will then be designed as shown in Figure 1.

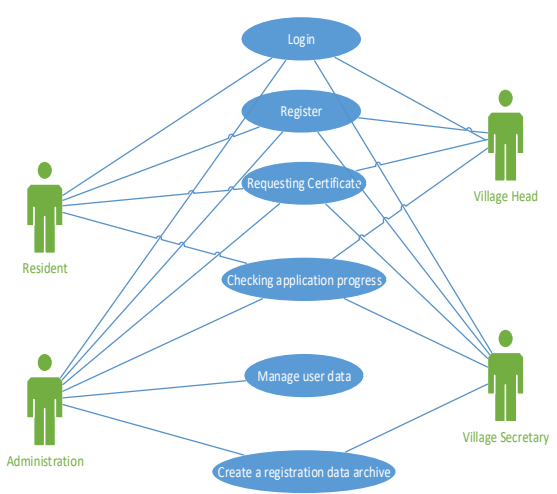

Fig. 1. Usecase Diagram.

The next stage is the implementation of the system design stage in the form of Usecase Diagrams and then implemented to create a Web-Based Village Data Information System.

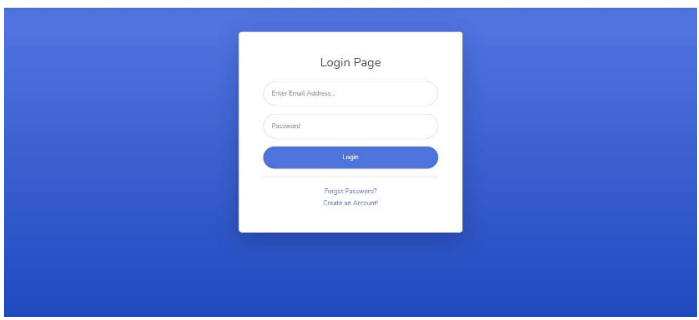

Fig. 2. Login page.

The first implementation is the login page. A login page has been created by entering the username and password as shown in Figure 2.

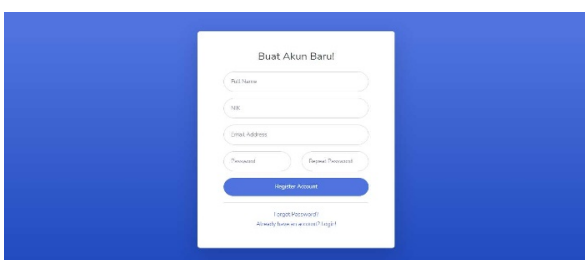

Fig. 3. Register page. 
The next implementation is the register page. A login page has been created by entering your name, NIK, Email and password as shown in Figure 3.

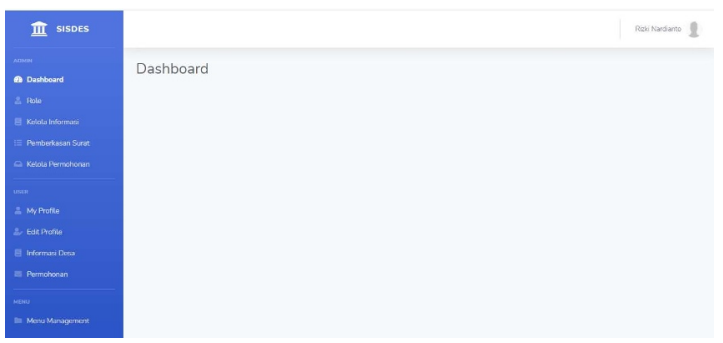

Fig. 4. Dashboard Page.

Figure 4 presents the results from the admin dashboard. There are menus, including Manage Information, File Files, Manage Applications.

This test is carried out to see the performance of the application that has been developed. Testing the application using the Blackbox Testing method and using the Mean Opinion Score (MOS) to see user opinions about the village information system. Blackbox Testing is a software testing method that is used to test software without knowing the internal structure of the program or just observing the functionality and execution of the software. The results of Blackbox testing can be seen in table 1 .

Table 1. Blackbox Testing Results.

\begin{tabular}{|c|c|c|}
\hline No & Tested function & Expected output \\
\hline 1 & $\begin{array}{c}\text { System login } \\
\text { page }\end{array}$ & Username and Password \\
\hline 2 & Main page & $\begin{array}{c}\text { Displays the main page of the } \\
\text { village information system }\end{array}$ \\
\hline 3 & Role page & $\begin{array}{c}\text { Displays the page for the user } \\
\text { role }\end{array}$ \\
\hline 4 & $\begin{array}{c}\text { Information } \\
\text { manage page }\end{array}$ & $\begin{array}{c}\text { Displays the manage } \\
\text { information page }\end{array}$ \\
\hline 5 & Mail Filing Page & Show Mail filing page \\
\hline 6 & $\begin{array}{c}\text { Manage } \\
\text { Applications }\end{array}$ & $\begin{array}{c}\text { Display the Application manage } \\
\text { page }\end{array}$ \\
\hline 7 & $\begin{array}{c}\text { User profile } \\
\text { Manage page }\end{array}$ & $\begin{array}{c}\text { Displays the Manage User } \\
\text { profile page }\end{array}$ \\
\hline 8 & $\begin{array}{c}\text { Village } \\
\text { information page }\end{array}$ & $\begin{array}{c}\text { Displaying the village } \\
\text { information page }\end{array}$ \\
\hline 9 & Application Page & Show Application Page \\
\hline 10 & Logout Page & $\begin{array}{c}\text { Delete all Sessions and display } \\
\text { the login page }\end{array}$ \\
\hline
\end{tabular}

The next testing stage, using the Mean Opinion Score (MOS) test MOS is one method that can be used to measure the quality and performance of the application or system that has been developed. MOS measurement is done by asking the respondent to answer several questions after the respondent has tried to use the system. Respondents were asked to give a value in the range of numbers 1 to 4 . Where the larger the number chosen, the better value. Then the average rating of all respondents is calculated so that the Mean Opinion Score value is obtained from the system. The MOS test is based on user acceptance test (UAT). This UAT was carried out by 5 respondents with 10 questions related to the system built by the author by giving the weight of the assessment which can be seen in Table 2.

The results of the analysis of the tests that have been carried out using UAT, obtained the Mean Opinion (MO) value which is presented in percentage as follows:

a) $95 \%$ of respondents stated that the Kelurahan Information System is easy to run

b) $90 \%$ of respondents stated that the appearance of the Kelurahan Information System is easy to use and understand

c) $60 \%$ of respondents stated that the user interface of the interactive Kelurahan Information System

d) $90 \%$ of respondents stated that the Kelurahan Information System really helps the community

e) $80 \%$ of respondents stated that the response time to access the facilities of each Kelurahan Information System was fast and stable

Table 2. Tabel Hasil Survei Pengujian Sistem.

\begin{tabular}{|c|c|c|c|c|c|}
\hline No & Question & SA & $\mathbf{A}$ & D & NA \\
\hline 1 & $\begin{array}{l}\text { The Village Information } \\
\text { System is easy to run }\end{array}$ & 4 & 1 & & \\
\hline 2 & $\begin{array}{l}\text { The appearance of the } \\
\text { Village Information System } \\
\text { is easy to use and understand }\end{array}$ & 3 & 2 & & \\
\hline 3 & $\begin{array}{l}\text { Display (user interface) of } \\
\text { the interactive Urban village } \\
\text { Information System }\end{array}$ & & 2 & 3 & \\
\hline 4 & $\begin{array}{l}\text { The Village Information } \\
\text { System is very helpful for } \\
\text { the community }\end{array}$ & 3 & 2 & & \\
\hline 5 & $\begin{array}{l}\text { The response time to access } \\
\text { the facilities of each system } \\
\text { is fast and stable }\end{array}$ & 2 & 2 & 1 & \\
\hline 6 & $\begin{array}{c}\text { The Village Information } \\
\text { System displays the } \\
\text { appropriate data }\end{array}$ & 2 & 3 & & \\
\hline 7 & $\begin{array}{l}\text { The Village Information } \\
\text { System produces the latest } \\
\text { information in a timely } \\
\text { manner }\end{array}$ & 3 & 1 & 1 & \\
\hline 8 & $\begin{array}{l}\text { the facilities in the Village } \\
\text { Information System Urban } \\
\text { village are complete }\end{array}$ & 2 & 2 & 1 & \\
\hline 9 & $\begin{array}{l}\text { Never had an } \\
\text { error/interference when } \\
\text { running the system }\end{array}$ & 2 & 1 & 2 & \\
\hline 10 & $\begin{array}{l}\text { Information on the Village } \\
\text { Information System is easy } \\
\text { to understand }\end{array}$ & 2 & 1 & 1 & 1 \\
\hline
\end{tabular}

\section{Conclusion}

This research has developed an Information System that has been used to assist Urban village Officers to manage village data. The village information system has the convenience of running it. The Village Information System is easy to use and understand. The Urban village information system is very helpful for the community as well as being fast and stable. 


\section{References}

[1] L. Hickman and M. Akdere, "Effective leadership development in information technology: building transformational and emergent leaders," Ind. Commer. Train., vol. 50, no. 1, pp. 1-9, (2018), doi: 10.1108/ICT-062017-0039.

[2] Y. Zheng, M. Hatakka, S. Sahay, and A. Andersson, "Conceptualizing development in information and communication technology for development (ICT4D)," Inf. Technol. Dev., vol. 24, no. 1, pp. 1-14, (2018), doi: 10.1080/02681102.2017.1396020.

[3] H. Sepehrdoust and M. Ghorbanseresht, "Kasetsart Journal of Social Sciences Impact of information and communication technology and fi nancial development on economic growth of OPEC developing economies," vol. 40, pp. 546-551, (2019).

[4] S. A. Asongu and N. M. Odhiambo, "How enhancing information and communication technology has affected inequality in Africa for sustainable development: An empirical investigation," Sustain. Dev., vol. 27, no. 4, pp. 647-656, (2019), doi: 10.1002/sd.1929.

[5] T. N. Theis and H. S. Philip Wong, "The End of Moore's Law: A New Beginning for Information Technology," Comput. Sci. Eng., vol. 19, no. 2, pp. 41-50, 2017), doi: 10.1109/MCSE.2017.29.

[6] S. M. Chege, D. Wang, and S. L. Suntu, "Impact of information technology innovation on firm performance in Kenya," Inf. Technol. Dev., vol. 26, no. 2, pp. 316-345, (2020), doi: 10.1080/02681102.2019.1573717.

[7] E. Hatef, E. C. Lasser, H. H. K. Kharrazi, C. Perman, R. Montgomery, and J. P. Weiner, “A population health measurement framework: Evidence-based metrics for assessing community-level population health in the global budget context," Popul. Health Manag., vol. 21, no. 4, pp. 261-270, (2018), doi:

10.1089/pop.2017.0112.

[8] F. Sudarto and A. Yondari, "Web-Based Population Cencus Design in Neighborhood Building," Aptisi Trans. Technopreneursh., vol. 2, no. 1, pp. 18-24, (2019), doi: 10.34306/att.v2i1.49.

[9] F. Haswan, "Design of a Web-Based Information System for Data Collection of Sungai Jering Village residents with Object Oriented Programming," J. Teknol. Dan Open Source, vol. 1, no. 2, pp. 92-100, (2018), doi: 10.36378/jtos.v1i2.23.

[10] A. Karim and E. Purba, "Web-Based Information System for Village Mosque Village Population Data Collection," Semin. Nas. Sains Teknol. Inf., pp. 537-545, (2018).

[11] R. E. D. Reyhannisa Erico Dwi Ramadhana and A. Fatmawati, "Financial Management Information System at Adh-Dhuha Islamic Boarding School," J. Tek. Inform., vol. 1, no. 2, pp. 93-99, (2020), doi:

10.20884/1.jutif.2020.1.2.20.

[12] F. A. Prabowo, "Web-Based Certificate Processing Information System in SEAMOLEC Training Training Division," J. Masy. Inform. Indones., vol. 2, no. 1, pp. 82-91, (2017).

[13] N. A. Rahmawati and A. C. Bachtiar, "Analysis and design of school library information systems based on system requirements," Berk. Ilmu Perpust. dan Inf., vol. 14, no. 1, p. 76, (2018), doi: 10.22146/bip.28943.

[14] A. Syafi, Z. Eka, M. Sari, and M. Arif, "DEVELOPMENT OF WEB-BASED ADMISSION INFORMATION SYSTEM IN SMA 1 ANNUQAYAH SUMENEP Abstract," J. Ilm. Edutic, vol. 4, no. 2, pp. 53-62, (2018).

[15] M Teguh Prihandoyo, "Unified Modeling Language (UML) Model for Web-Based Academic Information System Development," J. Inform. J. Pengemb. IT, vol. 3, no. 1, pp. 126-129, (2018).

[16] A. Brasoveanu, M. Moodie, and R. Agrawal, "Textual evidence for the perfunctoriness of independent medical reviews," CEUR Workshop Proc., vol. 2657, pp. 1-9, (2020), doi: 10.1145/nnnnnnn.nnnnnnn.

[17] X. Liu, Y. Xu, L. Jia, Q. Wu, and A. Anpalagan, "Anti-jamming communications using spectrum waterfall: A deep reinforcement learning approach," IEEE Commun. Lett., vol. 22, no. 5, pp. 998-1001, (2018), doi: 10.1109/LCOMM.2018.2815018.

[18] M. Kramer, "Lifecycle : An Analyses Based on the Waterfall Model," Rev. Bus. Financ. Stud., vol. 9, no. 1, pp. 77-84, (2018).

[19] A. M. Dima and M. A. Maassen, "From waterfall to agile software: Development models in the IT sector, 2006 to 2018. impacts on company management," J. Int. Stud., vol. 11, no. 2, pp. 315-326, (2018), doi: 10.14254/20718330.2018/11-2/21.

[20] B.-A. Andrei, A. Casu-Pop, S.-C. Gheorghe, and C.-A. Boiangiu, "A Study on Using Waterfall and Agile Methods in Software Project Management," J. Inf. Syst. Oper. Manag., no. June, pp. 125-135, (2019). 